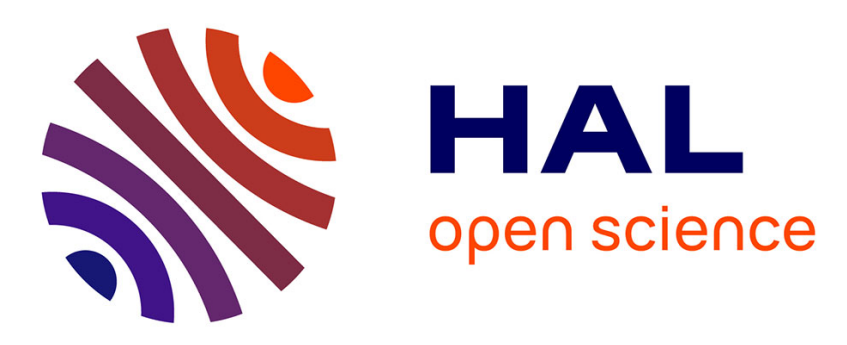

\title{
Effective CW and quasi-CW LBO frequency doubled Nd:YAG lasers
}

S. Bogdanov, V. Bondarenko, A. Fomichov, P. Konvissar, S. Rustamov

\section{To cite this version:}

S. Bogdanov, V. Bondarenko, A. Fomichov, P. Konvissar, S. Rustamov. Effective CW and quasiCW LBO frequency doubled Nd:YAG lasers. Journal de Physique IV Proceedings, 1994, 04 (C4), pp.C4-614-C4-614. 10.1051/jp4:19944164 . jpa-00252621

\section{HAL Id: jpa-00252621 https://hal.science/jpa-00252621}

Submitted on 1 Jan 1994

HAL is a multi-disciplinary open access archive for the deposit and dissemination of scientific research documents, whether they are published or not. The documents may come from teaching and research institutions in France or abroad, or from public or private research centers.
L'archive ouverte pluridisciplinaire HAL, est destinée au dépôt et à la diffusion de documents scientifiques de niveau recherche, publiés ou non, émanant des établissements d'enseignement et de recherche français ou étrangers, des laboratoires publics ou privés. 


\title{
Effective CW and quasi-CW LBO frequency doubled Nd:YAG lasers
}

\author{
S.F. BOGDANOV, V.G. BONDARENKO, A.A. FOMICHOV, P.G. KONVISSAR and \\ S.R. RUSTAMOV
}

Moscow Institute of Physics and Technology, Institutsky per. 9, 141700 Moscow Region, Dolgoprudny, Russia

Lithium borate $(\angle B O)$ is one of the nonlinear crystals for second and third harmonic generation of the Nd: YAG 1 asers. It has the most acceptable physical, optical and nonlinear optical propeties [I]. High convertion efficiency of Q-switch $N d: Y A G$ iasers was achived more than $70 \%$ for Type I, and more than $80 \%$ for Type II doubling). In the last time second harmonic output power up to IO with pump power about $4 \mathrm{~kW}$ in $\mathrm{CW}$ regime was obtained by us [2]. It was shown that LBO can use for creation powerful CW pumped and frequency doubled lasers.

At present we elaborate series of CW pumped frequensy doubled lasers working in different regimes with pump power up to $3 \mathrm{~kW}$. This new series is distinguished by good stability, small sizes, reliability, excellent Gausian structure of the output beam.

The specific of laser resonator is in the using of special Z-form spherical cavity with active rod $4 \times 80 \mathrm{~mm}$. The mirror's radi and the distance between the optical elements are optimized to achieve the stability of laser operation independently from change of thermal lense and optical wedge in laser rod. Spectral effects wich are in particular. connected with selective propeties of intracavity elements have great influence on second harmonic radiation stability. To stabilize output power we put into the cavity frequency and polarization selectors that suppress appearence of additional generation lines for which phase-matching is absent.

Heated crystals LBO with critical and noncritical type of phase-matching were used in our experiments. The best results was obtained with heated crystals when temperature was $70-90 \mathrm{C}$.

The main parameters of high power lasers with intracavity frequency doubling in LBO are quoted below.

- CW laser with intracavity frequency doubling pump power $2,5 \mathrm{kw}$, output power $-2 \ldots 3 \mathrm{~W}$.

- Q-switch laser with intracavity frequercy doubing pump power $-2,5 \mathrm{~W}$, output power - 3 ...5 $\mathrm{W}$, pulse repetition rate about IO kHz.

- Q-switch laser with extracavity frequency doubling: pump power $-2,5 \mathrm{~kW}$, output power - 3. . 4 with doubling efficiency up to $40 \%$, pulse repetition rate $-3 . .5 \mathrm{kHz}$.

- Q-switch mode-1ocked laser with extracavity frequency doubling: pump power $-2 \mathrm{~kW}$ output power $-0,5 \ldots 0,7 \mathrm{w}$ with doubling efficiency up to 55\% train repetition rate- I $\mathrm{kHz}$, ultrashort pulse repetition rate - I60 MHz, pulse length - 50 ps.
Referenses
I. S.P.Velsko, M. Webb, L.Davis, C. Huang. IEEE J. Quantum Eleqtron., v. 27, pp.2182-2I92, I99I.
2. V.G.Bondärenko, P.G. Konvissar, S.R.Rustamov. CLEO-93, CThSI6. 